\title{
Pengaruh Kandungan Protein Ransum yang Berbeda terhadap Kecernaan dan Fermentabilitas Rumen Sapi Perah secara In vitro
}

The Effect of Different Feed Protein Content on Digestibility and Fermentability of Dairy Rumen using In vitro

\author{
R Zahera1*, D Anggraeni', Z A Rahman², D Evvyernie ${ }^{1}$
}

Corresponding email:

zahera@apps.ipb.ac.id

1)Departemen Ilmu Nutrisi dan Teknologi Pakan, Fakultas Peternakan, Institut Pertanian Bogor (Bogor Agricultural University/IPB University)

2)Sekolah Menengah Analis Kimia Bogor Jalan Binamarga II, Baranangsiang, Bogor, Jawa Barat, Indonesia

\section{ABSTRACT}

The most of protein requirement for cows is fulfilled by microbial protein. Increasing the protein from ration usually influences the milk production in dairy cows. However, the availability of dietary protein should support rumen ecosystem through microbial activity in the fermentation and digestion process. The aim of this study was to evaluate the protein levels of dairy cow ration on the rumen fermentability and digestibility using an in vitro method. Randomized block design with three levels of protein ration as a treatment and three times taken of rumen liquor as a block. The treatments were: $\mathrm{R} 1=$ ration with low protein; $\mathrm{R} 2=$ ration with moderate protein and $\mathrm{R} 3=$ ration with high protein. The measured parameters were rumen fermentability (total VFA, N-NH3 and $\mathrm{pH}$ ), in vitro dry matter digestibility (IVDMD) and in vitro organic matter digestibility (IVOMD). The results showed that there were significantly increase in dry and organic matter digestibility $(\mathrm{p}<0.05)$, due to increasing the level of dietary protein, but there was no effect in the fermentability, except a slight increase in $\mathrm{N}-\mathrm{NH}_{3}$ concentration. The conclusion of this study was the highest level of protein ration enhances the digestibility, and showed a tendency for higher $\mathrm{N}-\mathrm{NH}_{3}$.

Key words: dairy cattle, dietary protein, digestibility, fermentability, in vitro

\section{ABSTRAK}

Sebagian besar kebutuhan protein untuk sapi perah dipenuhi oleh protein mikroba. Peningkatan protein dalam ransum dapat mempengaruhi produksi susu sapi perah. Akan tetapi, ketersediaan protein pakan harus mendukung ekosistem rumen melalui aktivitas mikroba dalam proses fermentasi dan pencernaan. Tujuan penelitian ini adalah untuk mengevaluasi pengaruh ransum dengan kandungan protein yang berbeda terhadap kecernaan dan fermentabilitas rumen sapi perah secara in vitro. Penelitian ini menggunakan rancangan acak kelompok dengan tiga perlakuan dan tiga kelompok. Pengambilan cairan rumen digunakan sebagai kelompok. Ransum perlakuan terdiri dari R1= ransum dengan protein rendah; R2= ransum dengan protein sedang dan R3= ransum dengan protein tinggi. Parameter yang diamati antara lain kecernaan bahan kering dan bahan organik, serta fermentabilitas rumen (total VFA, $\mathrm{N}-\mathrm{NH}_{3}$ dan $\mathrm{pH}$ ). Data dianalisis varian dan jika berbeda nyata dilanjutkan analisis polinomial ortogonal. Hasil menunjukkan perlakuan ransum dengan level protein yang berbeda memberikan pengaruh yang nyata terhadap kecernaan bahan kering dan bahan organik $(P<0,05)$, yang disebabkan peningkatan kandungan protein ransum, namun tidak mempengaruhi fermentabilitas rumen kecuali ada sedikit peningkatan konsentrasi $\mathrm{N}-\mathrm{NH}_{3}$. Kesimpulan dari penelitian ini, semakin tinggi kandungan protein ransum maka semakin tinggi pula kecernaan bahan kering dan organik, serta menunjukkan kecenderungan tingginya $\mathrm{N}$ $\mathrm{NH}_{3}$.

Kata kunci: fermentabilitas, in vitro, kecernaan, protein, sapi perah 


\section{PENDAHULUAN}

Peternakan sapi perah di Indonesia sebagian besar merupakan peternakan rakyat dan total produksi susu nasional yang dihasilkan hanya mampu memenuhi $20 \%$ kebutuhan susu nasional (Ditjetnak-Keswan 2019). Rendahnya produksi susu sapi perah, salah satunya dipengaruhi oleh pemasalahan pakan, terutama karena ketidakcukupan nutrien (Despal et al. 2011). Ketersediaan dan kualitas pakan sapi perah juga dipengaruhi oleh iklim dan tipologi wilayah. Terbatasnya bahan pakan pada musim kemarau menyebabkan rendahnya kualitas ransum yang diberikan peternak. Rataan kandungan protein ransum sebesar $10,17 \%$ pada musim kemarau lebih rendah dibandingkan pada musim hujan sebaesar 12,18\% (Despal et al. 2015).

Produksi susu merupakan salah satu faktor yang mempengaruhi kebutuhan nutrien sapi. Penyusunan ransum sapi perah dapat disesuaikan dengan produksi susu yang dihasilkan sehingga nutrien yang diberikan dapat dimanfaatkan secara efesien. Semakin tinggi produksi susu yang dihasilkan, semakin tinggi kandungan nutrien yang dibutuhkan (Imran et al. 2017). Namun, keterbatasan peternak dalam memformulasikan pakan menyebabkan pakan yang diberikan tidak memenuhi kebutuhan (Permana et al. 2017). Ketersediaan bahan pakan sumber protein merupakan salah satu faktor pembatas dalam penyusunan ransum sapi perah. Pemenuhan protein pada sapi perah sebagian besar berasal dari protein mikroba, sehingga aktivitas mikroba dalam proses fermentasi dan pencernaan akan mempengaruhi ketersediaan protein. Ransum komplit untuk sapi perah (Total Mix Ration) dengan kandungan protein tinggi juga menunjukkan tingginya produksi susu yang dihasilkan (Sucak et al. 2017). Tingginya protein yang mudah difermentasi dalam rumen juga dapat meningkatkan efisiensi pemanfaatan nitrogen (Law et al. 2009) dan menghasilkan ekskresi nitrogen yang minimal (Nadeau et al. 2007).

Ransum sapi perah dengan kandungan protein yang berbeda dapat dimanfaatkan untuk sapi perah dengan beberapa tingkat produksi susu. Penelitian ini menguji kualitas ransum dengan kandungan protein berbeda berdasarkan kebutuhan sapi perah pada tingkat produksi susu yang berbeda. Peningkatan kandungan protein ransum dapat meningkatkan metabolisme protein sehingga sumber $\mathrm{N}$ bagi sintesis protein mikroba terpenuhi dan tingginya protein yang lolos degradasi rumen (Rumen Undegradable Protein/RUP), hal ini juga berdampak positif terhadap kecernaan bahan kering dan organik (Colmenero \& Broderick 2006), serta produksi susu sapi perah (Leonardi et al. 2003; Imran et al. 2017). Pemberian konsentrat dengan kandungan protein yang lebih tinggi dapat meningkatkan kecernaan bahan kering dan organik, produksi N-NH3, VFA, dan protein mikroba
Tabel 1 Formulasi ransum perlakuan

\begin{tabular}{lccc}
\hline Perlakuan & R1 & R2 & R3 \\
\hline $\begin{array}{l}\text { Rumput Gajah } \\
\text { Konsentrat Sapi Perah }\end{array}$ & 50 & 50 & 50 \\
$\begin{array}{l}\text { Bungkil Kedelai } \\
\text { Onggok }\end{array}$ & 15 & 50 & 40 \\
\hline Kandungan Nutrient (\% BK) & & & 10 \\
\hline Abu & 9,06 & 9,86 & 9,90 \\
Lemak Kasar & 3,42 & 4,24 & 3,92 \\
$\begin{array}{l}\text { Protein Kasar } \\
\text { Serat Kasar }\end{array}$ & 10,48 & 12,69 & 15,71 \\
$\begin{array}{l}\text { Bahan Ekstrak Tanpa } \\
\text { Nitrogen (BETN) }\end{array}$ & 21,60 & 22,03 & 21,44 \\
$\begin{array}{l}\text { Total Digestible Nutrien } \\
\text { (TDN) }\end{array}$ & 61,81 & 43,81 & 42,80 \\
Rasio PK/TDN & 0,17 & 61,78 & 61,14 \\
\hline
\end{tabular}

(Dung et al. 2014). Tujuan penelitian ini adalah untuk mengevaluasi pengaruh ransum dengan kandungan protein yang berbeda terhadap kecernaan dan fermentabilitas rumen sapi perah secara in vitro.

\section{METODE}

\section{Cairan Rumen Ternak dan Ransum}

Cairan rumen yang digunakan berasal dari sapi perah Frisian Holstein jantan berfistula yang dipelihara dari Laboratorium Lapang Nutrisi Ternak Perah, Fakultas Peternakan, Institut Pertanian Bogor. Bahan pakan yang digunakan pada penelitian ini antara lain rumput gajah, konsentrat sapi perah, bungkil kedelai, dan onggok. Formulasi ransum perlakuan disusun berdasarkan (NRC 1978) untuk memenuhi kebutuhan sapi perah dengan produksi susu $10 \mathrm{~L}$ (R1), 15 L(R2), dan 20L (R3) dapat dilihat pada Tabel 1.

\section{Pengukuran Kecernaan Bahan Kering (KCBK) dan Bahan Organik (KCBO) secara In vitro}

Metode in vitro dilakukan berdasarkan metode Tilley dan Terry (1963). Sebanyak 0,5 g sampel dimasukkan ke dalam tabung fermentor volume $100 \mathrm{~mL}$, kemudian ditambahkan $40 \mathrm{~mL}$ laruten buffer McDougall dan $10 \mathrm{~mL}$ cairan rumen, kemudian diberi gas $\mathrm{CO}_{2}$ selama 30 detik,

Tabel 2 Kandungan nutrien konsentrat sapi perah

\begin{tabular}{|c|c|}
\hline Nutrien & Persentase (\%) \\
\hline Bahan Kering 1) & 88,44 \\
\hline $\mathrm{Abu}^{1)}$ & 7,71 \\
\hline Lemak Kasar ${ }^{1)}$ & 5,77 \\
\hline Protein Kasar1) & 16,68 \\
\hline Serat Kasar ${ }^{1)}$ & 11,76 \\
\hline BETN $^{11}$ & 46,52 \\
\hline TDN²) & 66,56 \\
\hline
\end{tabular}


ditutup rapat dengan prop karet berventilasi, dan diinkubasi dalam shacker water bath dengan suhu $39^{\circ} \mathrm{C}$. Setelah inkubasi selama 4 jam, sampel diambil untuk analisis Volatil Fatty Acid (VFA) total dan $\mathrm{N}-\mathrm{NH}_{3}$. Setelah diinkubasi selama 48 jam, sampel ditambahkan 2-3 tetes $\mathrm{HgCl}_{2}$ jenuh, kemudian disentrifus dengan kecepatan 3000 rpm selama 15 menit dan supernatannya dibuang, ke dalam tabung ditambahkan $50 \mathrm{ml}$ larutan pepsin $\mathrm{HCl}$ $0,2 \%$. Pencernaan enzimatis berlangsung aerob selama 48 jam. Hasil pencernaan hidrolisis (residu) disaring menggunakan kertas Whatman No. 41 yang dibantu dengan pompa vakum. Kemudian residu tersebut dimasukkan ke dalam cawan porselen dan dipanaskan di dalam oven suhu $105^{\circ} \mathrm{C}$ selama 24 jam untuk 16 menentukan BK residu. Selanjutnya residu BK dimasukkan ke dalam tanur selama 6 jam. Kemudian Kecernaan Bahan Kering (KCBK) dan Kecernaan Bahan Organik (KCBO) dihitung berdasarkan rumus:

$$
\begin{array}{ll}
\text { KCBK }(\%) & =\frac{\text { BKsampel }-(\text { BKresidu }- \text { BKblanko })}{\text { BKsampel }} \times 100 \\
\text { KCBK }(\%) & =\frac{\text { BOsampel-(BOresidu-BOblanko) }}{\text { BOsampel }} \times 100
\end{array}
$$

\section{Pengukuran pH Rumen}

Sampel dari fermentasi rumen diukur dengan $\mathrm{pH}$ meter. Nilai $\mathrm{pH}$ yang diambil merupakan rataan nilai $\mathrm{pH}$ dengan pengukuran duplo.

\section{Pengukuran Produksi Volatil Fatty Acid (VFA) Total}

Produksi VFA total diukur menggunakan teknik destilasi uap. Supernatan sebanyak $5 \mathrm{~mL}$ dimasukkan ke dalam tabung destilasi, lalu segera ditambahkan dengan $1 \mathrm{~mL}$ $\mathrm{H}_{2} \mathrm{SO}_{4} \quad 15 \%$ dan ditutup dengan tutup karet yang mempunyai lubang dan dapat dihubungkan dengan labu pendingin. Tabung destilasi dimasukkan ke dalam labu penyulingan yang berisi air mendidih. Uap air panas akan mendesak campuran supernatan dan $\mathrm{H}_{2} \mathrm{SO}_{4}$ kemudian terkondensasi dalam labu 13 pendingin. Air yang terbentuk ditampung dalam labu erlenmeyer yang berisi $5 \mathrm{~mL} \mathrm{NaOH} \mathrm{0,5} \mathrm{N}$ hingga sampel menjadi $250 \mathrm{~mL}$, kemudian ditambahkan dengan indikator PP (Phenol Pthaline) sebanyak 2-3 tetes dan dititrasi dengan $\mathrm{HCl}$ $0,5 \mathrm{~N}$ sampai warna titrat berubah dari merah jambu menjadi tidak berwarna. Produksi VFA total dapat dihitung dengan rumus sebagai berikut:

VFA total $(\mathrm{mM})=\frac{(\mathrm{a}-\mathrm{b}) \mathrm{NHClx}\left(\frac{1000}{5}\right)}{\text { gsampel } \times \text { BKsampel }} \times 100$

Keterangan:

$\mathrm{a}=$ volume titran blanko $(\mathrm{mL})$

$\mathrm{b}=$ volume titran sampel $(\mathrm{mL})$

\section{Pengukuran Produksi N-NH}

Pengukuran Produksi $\mathrm{N}_{-} \mathrm{NH}_{3}$ diukur menggunakan metode mikrodifusi menggunakan cawan Conway (Conway 1957). Cawan Conway diolesi vaselin, lalu sebanyak $1 \mathrm{~mL}$ sampel ditempatkan pada ujung jalur cawan Conway tersebut. Kemudian $1 \mathrm{~mL}$ larutan $\mathrm{Na}_{2} \mathrm{CO}_{3}$ diletakkan pada sisi yang bersebelahan dengan sampel. Sebanyak $1 \mathrm{~mL}$ asam borat berindikator ditempatkan di bagian tengah cawan Conway, kemudian ditutup rapat. Cawan Conway dimiringkan agar supernatan dan larutan $\mathrm{Na}_{2} \mathrm{CO}_{3}$ tercampur hingga merata. Didiamkan selama 24 jam pada suhu kamar dan setelah 24 jam asam borat berindikator dititrasi menggunakan $\mathrm{H}_{2} \mathrm{SO}_{4}$ sampai terjadi perubahan warna dari biru menjadi merah. Kadar $\mathrm{NH}_{3}$ dihitung dengan rumus:

$\mathrm{N}-\mathrm{NH}_{3}(\mathrm{mM})=\frac{\mathrm{mLH} 2 \mathrm{SO} 4 \times \mathrm{NH} 2 \mathrm{SO} 4 \times 1000}{\text { gsampelxBKsampel }}$

\section{Rancangan Percobaaan dan Analisis Data}

Penelitian ini menggunakan rancangan acak kelompok dengan tiga kelompok berdasarkan pengambilan cairan rumen. Perlakuan yang diberikan adalah ransum dengan kandungan protein yang berbeda, antara lain R1= ransum dengan protein rendah; R2= ransum dengan protein sedang dan $\mathrm{R} 3=$ ransum dengan protein tinggi. Hasil yang diperoleh dianalisis menggunakan Analysis of Variance (ANOVA) dan jika terdapat perbedaan yang nyata dilakukan uji Polinomial Ortognal.

\section{HASIL DAN PEMBAHASAN}

Kecernaan bahan kering dan organik menunjukkan banyaknya pakan yang didegradasi oleh mikroba rumen dan dicerna oleh enzim pasca rumen (Zahera et al. 2015). Kecernaan bahan kering (KCBK) dan bahan organik (KCBO) terhadap ransum dengan kandungan protein berbeda dapat dilihat pada Tabel 3. Nilai KCBK dan KCBO ransum yang dihasilkan masing-masing berkisar 66,20\%-71,57\% dan 64,85\%-70,84\%. Lestari et al. (2015) juga melaporkan KCBK pada beberapa ransum sapi perah di peternakan rakyat berkisar 66,46\%$70,71 \%$. Tingginya kecernaan bahan kering dan bahan organik yang dihasilkan menunjukkan ransum sapi

Tabel 3 Kecernaan dan fermentabilitas rumen sapi perah terhadap ransum dengan kandungan protein berbeda

\begin{tabular}{lrrrr}
\hline Parameter & R1 & R2 & R3 & P-v \\
\hline KCBK (\%) & $66,20 \pm 1,53$ & $69,34 \pm 2,56$ & $71,57 \pm 1,02$ & 0,009 \\
KCBO (\%) & $64,85 \pm 2,19$ & $68,84 \pm 3,15$ & $70,84 \pm 1,44$ & 0,006 \\
VFA (mM) & $113,99 \pm 18,60$ & $101,72 \pm 17,05$ & $131,50 \pm 22,11$ & 0,310 \\
N-NH3 (mM) & $7,45 \pm 1,79$ & $6,69 \pm 1,15$ & $8,51 \pm 1,65$ & 0,064 \\
pH & $6,81 \pm 0,05$ & $6,82 \pm 0,04$ & $6,85 \pm 0,07$ & 0,414 \\
\hline P-v = P-value & & & &
\end{tabular}




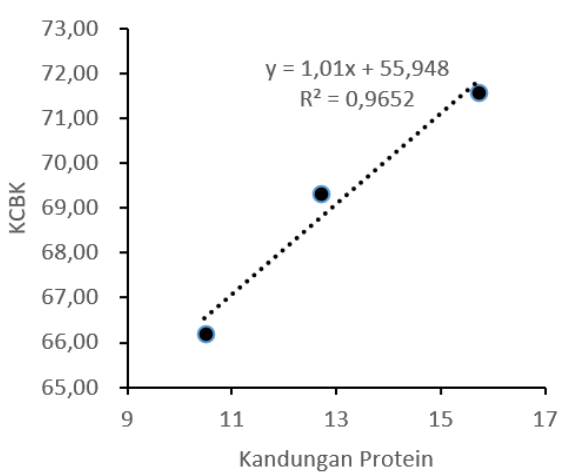

Gambar 1. Hubungan kandungan protein dengan kecernaan bahan kering secara in vitro

perah dengan rasio hijauan:konsentrat 50:50 yang berbasis rumput gajah dengan kandungan protein yang berbeda dapat dicerna dengan baik oleh sapi perah. Nilai kecernaan ini lebih tinggi dibandingkan ransum sapi perah dengan dengan rasio hijauan:konsentrat 50:50 dengan menggunakan jerami sebagai sumber hijauannya menunjukkan nilai KCBK dan KCBO yang lebih rendah masing-masing berkisar $43,53-64,68 \%$ dan 34,4058,70\% (Hernaman et al. 2017). Hal ini disebabkan kandungan nutrien jerami yang lebih rendah dibandingkan rumput gajah.

Ransum dengan kandungan protein yang berbeda menunjukkan pengaruh yang sangat nyata terhadap KCBK dan KCBO. Hubungan antara kandungan protein ransum dengan KCBK dan KCBO dapat dilihat pada Gambar 1 dan 2. Semakin tinggi kandungan protein ransum juga dapat meningkatkan KCBK dan KCBO secara in vitro dengan nilai masing-masing $\mathrm{r}^{2}=0,9903$ dan $\mathrm{r}^{2}=$ 0,9646 . Hubungan positif antara kandungan protein dengan kecernaan bahan kering dan bahan organik juga sama dilaporkan pada beberapa penelitian (Colmenero and Broderick 2006; Shahzad et al. 2011; Hernaman et al. 2017). Hubungan linear positif antara kandungan protein dan kecernaan menunjukkan protein hingga $15,71 \%$ masih belum nenunjukkan level protein optimum, hal ini karena kebutuhan protein pada sapi perah masih dapat meningkatkan berdasarkan produksi susu yang dihasilkan (NRC 2001).

Kecernaan berhubungan dengan komposisi energi dan nutrien pakan yang dapat dimanfaatkan oleh ternak (Forejtová et al. 2005). Suplai energi dalam rumen merupakan salah satu faktor penting dalam pemanfaatan $\mathrm{N}$-protein untuk sintesis protein mikroba. Tingginya kecernaan juga menunjukkan adanya penyediaan rumen degradable protein (RDP) dan energi dalam bentuk readily available carbohydrate (RAC) yang cukup untuk pertumbuhan mikroba rumen (Anggraeny et al. 2015). Tingginya kandungan protein ransum menunjukkan banyaknya nutrien, terutama $\mathrm{N}$-protein yang tersedia untuk didegradasi dan dicerna, sehingga dapat

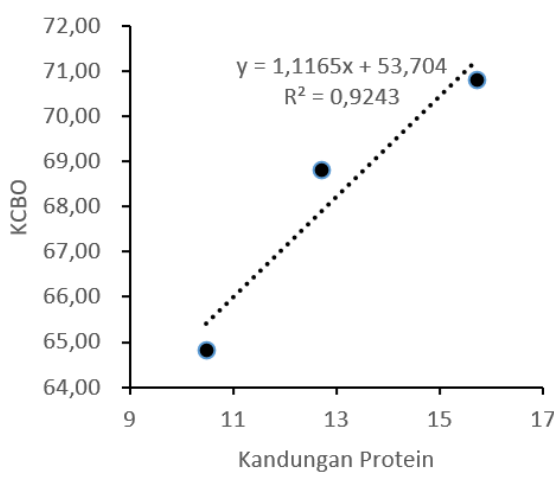

Gambar 2. Hubungan kandungan protein dengan kecernaan bahan organik secara in vitro

meningkatkan kecernaan, memperbaiki pertumbuhan mikroba dan mensuplai tingginya asam amino (Sucak et al. 2017). Protein dalam ransum menunjukkan ketersediaan $\mathrm{N}$ bagi mikroba rumen yang dapat membantu pertumbuhan mikroba dan produksi sintesis mikroba dalam mencerna nutrien, sehingga semakin tinggi kandungan protein juga dapat meningkatkan KCBK dan KCBO ransum sapi perah (Dung et al. 2014). Tingginya protein yang dapat dicerna dan diserap pada organ pasca rumen juga dapat meningkatkan produksi susu sapi perah (Imran et al. 2017).

Fermentabilitas rumen sapi perah ( $\mathrm{pH}, \mathrm{VFA}$ total, dan $\mathrm{N}-\mathrm{NH}_{3}$ ) juga dapat dilihat pada Tabel 3. Ransum dengan kandungan protein berbeda tidak memberikan pengaruh yang nyata terhadap $\mathrm{pH}$ rumen yang dihasilkan. Hal ini juga menunjukkan kandungan protein ransum yang berkisar $10-16 \%$ tidak menggangu proses fermentasi dan kecernaan di dalam rumen. Nilai pH rumen berperan penting dalam mengatur pertumbuhan mikroba rumen, memproduksi VFA dan $\mathrm{N}-\mathrm{NH}_{3}$. Penurunan $\mathrm{pH}$ rumen dapat dipengaruhi oleh beberapa faktor, seperti rasio konsentrat yang terlalu tinggi, rendahnya konsumsi ransum, rendahnya waktu ruminasi, rendahnya produksi saliva (Saha et al. 2019). Kondisi pH yang sesuai menunjukkan proses pertumbuhan dan metabolisme mikroba tidak akan terganggu sehingga proses pencernaan ransum akan optimal (Suharti et al. 2018).

Ransum dengan kandungan protein berbeda juga tidak memberikan pengaruh yang nyata terhadap VFA total yang dihasilkan. Nilai VFA total ransum yang dihasilkan berkisar 101,71-131,50 mM. Produksi VFA total menunjukkan bahan organik yang mudah didegradasi oleh mikroba rumen yang dimanfaatkan sebagai sumber energi bagi ruminansia (Joo et al. 2005). Hal ini menunjukkan produksi VFA total dapat menjadi indikator fermentabilitas rumen yang merupakan hasil proses degradasi karbohidrat oleh mikroba rumen (Xia et al. 2018). Produksi VFA yang digunakan untuk pertumbuhan optimum mikroba rumen, yaitu dengan kisaran 70-150 mM (McDonald et al. 2010). Produksi 
VFA total yang terdapat pada kisaran normal menunjukkan ransum sapi perah dengan kandungan protein kisaran $10-16 \%$ pada penelitian ini dapat menghasilkan VFA total yang optimum untuk pertumbuhan mikroba rumen. Tingginya kecernaan nutrien dengan produksi VFA total yang optimum pada penelitian ini menunjukkan adanya keseimbangan ketersediaan sumber energi dan protein dalam proses degradasi di dalam rumen. Adanya keseimbagan energi dan protein dalam ransum dapat meningkatkan efisien sintesis protein mikroba, sehingga nutrien yang dapat dicerna dan diserap pada pasca rumen juga meningkat (Anggraeny et al. 2015).

Ransum dengan kandungan protein berbeda juga tidak memberikan pengaruh yang nyata terhadap konsentrasi $\mathrm{N}^{-\mathrm{NH}_{3}}$ yang dihasilkan. Namun, ada kecenderungan peningkatan $\mathrm{N}^{-\mathrm{NH}_{3}}$ dengan meningkatnya kandungan protein ransum $(\mathrm{P}=0,064)$, terutama pada perlakuan $\mathrm{R} 3$. Nilai $\mathrm{N}-\mathrm{NH}_{3}$ ransum yang dihasilkan berkisar 6,69-8,51 mM. Konsentrasi ammonia yang optimal untuk aktivitas mikroba rumen adalah lebih besar dari 4,86 mM (McMurphy et al. 2011). Hal ini menunjukkan ransum sapi perah pada penelitian ini dapat menghasilkan konsentrasi yang optimal untuk pertumbuhan mikroba rumen. Adanya kecenderungan peningkatan konsentrasi ammonia pada perlakuan R3, dapat disebabkan oleh meningkatnya kandungan protein ransum (Cherdthong \& Wanapat 2013). Protein dipecah menjadi peptida dan asam amino oleh mikroba rumen, kemudian beberapa asam amino mengalami deaminasi menjadi amonia yang akan digunakan oleh mikroba rumen dalam sintesis protein mikroba (McDonald et al. 2010). Oleh karena itu, konsentrasi $\mathrm{N}-\mathrm{NH}_{3}$ yang tinggi menunjukkan protein pakan yang mudah didegrasi oleh mikroba rumen (Despal et al. 2011). Beberapa penelitian juga menunjukkan tingginya protein pakan juga dapat meningkatkan konsentrasi $\mathrm{N}^{-\mathrm{NH}_{3}}$ pada ternak ruminansia (Chanthakhoun et al. 2012; Dung et al. 2014; Holik et al. 2019). Tingginya kecernaan bahan kering dan bahan organik pada penelitian ini, menunjukkan sumber $\mathrm{N}$ untuk sintesis mikroba rumen sudah optimal sehingga tingginya protein yang dapat diserap pada organ pasca rumen (Colmenero \& Broderick 2006).

\section{SIMPULAN}

Kandungan protein ransum yang berbeda dapat mempengaruhi kecernaan bahan kering dan bahan organik secara in vitro, tanpa mempengaruhi fermentabilitas rumen. Peningkatan kandungan protein ransum hingga $15,71 \%$ dapat meningkatkan kecernaan bahan kering dan bahan organik. Dengan demikian, diharapkan akan banyak nutrien yang diserap pada organ pasca rumen untuk selanjutnya berperan dalam peningkatan produksi susu.

\section{DAFTAR PUSTAKA}

[Ditjennak-Keswan] Direktorat Jendral Peternakan dan Kesehatan Hewan. 2019. Pemerintah dorong perbaikan kualitas dan kuantitas susu nasional [internet]. Tersedia pada: http://ditjennak.pertanian.go.id/pemerintah-dorongperbaikan-kualitas-dan-kuantitas-susu-nasional

Anggraeny YN, Soetanto H, Kusmartono \& Hartutik. 2015. Sinkronisasi suplai protein dan energi dalam rumen untuk meningkatkan efisiensi pakan berkualitas rendah. WARTAZOA. 25(3):107-116

Chanthakhoun V, Wanapat M \& Berg J. 2012. Level of crude protein in concentrate supplements influenced rumen characteristics, microbial protein synthesis and digestibility in swamp buffaloes (Bubalus bubalis). Livestock Science. 144(3):197-204.

Cherdthong A \& Wanapat M. 2013. Manipulation of in vitro ruminal fermentation and digestibility by dried rumen digesta. Livestock Science. 153(1-3):94-100.

Colmenero JJO \& Broderick GA. 2006. Effect of dietary crude protein concentration on milk production and nitrogen utilization in lactating dairy cows. Journal of Dairy Science. 89(5):1704-1712.

Conway E. 1957. Microdiffusion of Analysis of Association Official Analytical Chemist. Georgia (US): Georgia Press.

Despal, Permana IG, Safarina SN \& Tatra AJ. 2011. Penggunaan berbagai sumber karbohidrat terlarut air untuk meningkatkan kualitas silase daun rami. Media Peternakan. 34(2):69-76.

Despal, Zahera R, Lestari DA, Ma'rifah H \& Permana IG. 2015. Ketersediaan dan kualitas sumberdaya pakan musim kemarau dan dampaknya terhadap pemenuhan nutrien dan performa sapi perah di Pangalengan Kabupaten Bandung. Sumedang (ID): Seminar Nasional Peternakan Berkelanjutan, Universitas Pajajaran

Dung DV, Shang W \& Yao W. 2014. Effect of crude protein levels in concentrate and concentrate levels in diet on in vitro fermentation. Asian-Australasian Journal of Animal Science. 27(6):797-805.

Forejtová J, Lád F, Třináctý J, Richter M, Gruber M, Doležal P, Homolka P \& Pavelek L. 2005. Comparison of organic matter digestibility determined by in vivo and in vitro methods. Czeh Journal of Animal Science. 50(2):47-53.

Hernaman I, Tarmidi AR \& Dhalika T. 2017. Kecernaan in vitro ransum sapi perah berbasis jerami padi yang mengandung konsentrat yang difermentasi oleh Saccharomyces cerevisiae dan Effective Microorganisms-4 (EM-4). Majalah Ilmu Peternakan. 20(2):4548.

Holik YLA, Abdullah L \& Karti PDMH. 2019. Evaluasi nutrisi silase kultivar baru tanaman sorgum (Sorghum bicolor) dengan penambahan legum Indigofera sp. pada taraf berbeda. Jurnal Ilmu Nutrisi dan Teknologi Pakan. 17(2):38-46.

Imran M, Pasha TN, Shahid MQ, Babar I \& Naveed M. 2017. Effect of increasing dietary metabolizable protein on nitrogen efficiency in Holstein dairy cows. Asian-Australasian Journal of Animal Science. 30(5):660-665.

Joo JW, Bae GS, Min WK, Choi HS, Maeng WJ, Chung YH \& Chang MB. 2005. Effect of protein sources on rumen microbial protein synthesis using rumen simulated continuous culture system. Asian-Australasian Journal of Animal Science. 18(3):326-331.

Law RA, Young FJ, Patterson DC, Kilpatrick DJ, Wylie ARG \& Mayne CS. 2009. Effect of dietary protein content on animal production and blood metabolites of dairy cows during lactation. Journal of Dairy Science. 92(3):1001-1012. 
Leonardi C, Stevenson M \& Armentano LE. 2003. Effect of two levels of crude protein and methionine supplementation on performance of dairy cows. Journal of Dairy Science. 86(12):4033-4042.

Lestari DA, Abdullah L \& Despal. 2015. Comparative study of milk production and feed efficiency based on farmer best practices and National Research Council. Media Peternakan. 38(2): 110117

McDonald P, Edwards R, Greenhalgh J, Morgan C, Sinclair L \& Wilkinson R. 2010. Animal Nutrition. Seventh Ed. London (UK): Pearson Education

McMurphy C, Duff G, Sanders S, Cuneo S \& Chirase N. 2011. Effects of supplementing humates on rumen fermentation in Holstein steers. South Asian-Australasian Journal of Animal Science. 41(2):134-140.

Nadeau E, Englund J \& Gustafsson AH. 2007. Nitrogen efficiency of dairy cows as affected by diet and milk yield. Livestock Science. 111(12):45-56.

NRC. 1978. Nutrient Requirements of Dairy Cattle. 5th Revised Ed. Washington (US): National Academy Press.

NRC. 2001. Nutrient Requirement of Dairy Cattle. 7th Revised Ed Washington (US): National Academy Press

Permana IG, Despal, Zahera R \& Damayanti E. 2017. Evaluasi kecukupan nutrien, produksi dan kualitas susu sapi perah di peternakan rakyat. Bogor (ID): Seminar Nasional Industri Peternakan, Fakultas Peternakan IPB.

Saha S, Gallo L, Bittante G, Schiavon S, Bergamaschi M, Gianesella M \& Fiore E. 2019. Rumination time and yield, composition, lactating holstein cows. Animals. 9(2):1-13.

Shahzad MA, Tauqir NA, Ahmad F, Nisa MU, Sarwar M \& Tipu MA. 2011. Effects of feeding different dietary protein and energy levels on the performance of 12 - 15-month-old buffalo calves. Tropical Animal Health Production. 43(3):685-694.

Sucak MG, Serbester U \& Görgülü M. 2017. Effects of dietary starch and crude protein levels on milk production and composition of dairy cows fed high concentrate diet. Turkish Journal of Agriculture Food Science and Technology. 5(6):563-567.

Suharti S, Aliyah DN \& Suryahadi. 2018. Karakteristik fermentasi rumen in vitro dengan penambahan sabun kalsium minyak nabati pada buffer yang berbeda. Jurnal Ilmu Nutrisi dan Teknologi Pakan. 16(3):56-64.

Xia C, Aziz M, Rahman U, Yang H, Shao T, Qiu Q, Su H \& Cao B. 2018. Effect of increased dietary crude protein levels on production performance, nitrogen utilization, blood metabolites and ruminal fermentation of Holstein bulls. Asian-Australasian Journal of Animal Science. 31(10):1643-1653.

Zahera R, Permana IG \& Despal. 2015. Utilization of mungbean's greenhouse fodder and silage in the ration for lactating dairy cows. Media Peternakan. 38(2):123-131 